\title{
Influence of Day and Night Temperatures on Sweet Pepper Seedling Development
}

\author{
Yaping $\mathrm{Si}^{1}$ and Royal $\mathrm{D}$. Heins ${ }^{2}$ \\ Department of Horticulture, Michigan State University, East Lansing, Michigan 48824-1325
}

\begin{abstract}
Sweet pepper (Capsicum annuum 'Resistant Giant no. 4') seedlings were grown for 6 weeks in 128-cell plug trays under 16 day/night temperature (DT/NT) regimes from 14 to $26^{\circ} \mathrm{C}$. Seedling stem length, internode length, stem diameter, leaf area, internode and leaf count, plant volume, shoot dry weight (DW), seedling index, and leaf unfolding rate (LUR) were primarily functions of average daily temperature (ADT); i.e., DT and NT had similar effects on each growth or development parameter. Compared to ADT, the difference (DIF, where DIF = DT - NT) between DT and NT had a smaller but still statistically significant effect on stem and internode length, leaf area, plant volume, stem diameter, and seedling index. DIF had no effect on internode and leaf count, shoot DW, and LUR. The root : shoot ratio and leaf reflectance were affected by DT and DIF. Positive DIF (DT higher than NT) caused darker-green leaf color than negative DIF. The node at which the first flower initiated was related to NT. The number of nodes to the first flower on pepper plugs grown at 26 ${ }^{\circ} \mathrm{C}$ NT was 1.2 fewer than those of plants grown at $14{ }^{\circ} \mathrm{C}$ NT.
\end{abstract}

Day temperature (DT), night temperature (NT), average daily temperature (ADT), and differences between day and night temperature (DIF) control plant morphology and physiology. Went $(1944,1952,1957)$ showed stem elongation was affected by DT and NT; plant height increased as DT increased and NT decreased. Pinthus and Meiri (1979) showed that reversing DT/NT from 18/ $10^{\circ} \mathrm{C}$ to $10 / 18^{\circ} \mathrm{C}$ reduced leaf and stem elongation and promoted tillering in wheat (Triticum aestivum L.). Internode length of Lilium longiflorum Thunb. is highly correlated with DIF; internode length increased $482 \%$ as DIF increased from -16 to $16^{\circ} \mathrm{C}$ (Erwin et al., 1989). Lycopersicon esculentum L. plants grown under negative DIF (NT>DT) typically are shorter than those grown under positive DIF (DT $>$ NT) (Berghage et al., 1991; Erwin et al., 1992). Agrawal et al. (1993) reported that negative DIF reduced plant height, node count, fresh weight, dry weight (DW), and leaf area in Cucumis sativus L. Managing DT/NT fluctuations during a 24-h period is one method to control stem elongation (Erwin, 1991; Erwin et al., 1989, 1992; Heins and Erwin, 1990), since stem length increases as DIF increases (Heins and Erwin, 1990; Tageras, 1979).

Air and soil temperature have a marked effect on pepper (Capsicum anпиum) plant development and flowering; as temperature decreases, development rate decreases (Deli and Tiessen, 1969; Rylski, 1972). Rylski (1972) showed that high soil and night temperatures reduced the number of leaves that developed from the cotyledon stage until flowering.

Many peppers are produced as plugs for transplanting into fields to produce fruit. Controlling height during the plug stage is essential to avoid excessively tall plants at transplant, and inducing flowers before transplant may hasten early production. The objectives of this research were to determine the response of pepper seedlings to DT, NT, and DIF and to determine how this information might be used to produce mature, compact pepper seedlings.

Received for publication 22 May 1995. Accepted for publication 9 Feb. 1996. We gratefully acknowledge the support of the Michigan Agricultural Experiment Station. The cost of publishing this paper was defrayed in part by the payment of page charges. Under postal regulations, this paper therefore must be hereby marked advertisement solely to indicate this fact.

${ }^{1}$ Visiting professor. Current address: Beijing Vegetable Research Centre, South Kung Ming Road, West Suburb, P.O. Box 2443, Beijing, China 100081.

${ }^{2}$ Professor.

\section{Materials and Methods}

Two pepper ('Resistant Giant no. 4') seeds were sown per cell in 128-cell plug trays $(29 \times 29 \times 50 \mathrm{~mm} /$ cell $)$ containing Metro Mix 510 growing medium (Grace/Sierra, Fogelsville, Pa.) and were covered with about $2 \mathrm{~mm}$ of fine vermiculite. The trays were placed for 17 days in a greenhouse maintained at $21^{\circ} \mathrm{C}$ under natural sunlight for germination and early seedling growth. When the first true leaf started to expand, a 100\% stand was established by thinning plants to one uniform seedling per cell. Plant flats then were placed randomly on tables in one of four $\left(15.1-\mathrm{m}^{3}\right)$ walk-in growth chambers (model UWP 3009-2; Hotpack, Philadelphia, Pa.) maintained at $14,18,22$, and $26^{\circ} \mathrm{C}$. Plant trays were moved among chambers at 0800 and $1900 \mathrm{HR}$ each day to provide $16 \mathrm{DT} /$ NT combinations. Moving plants required about $20 \mathrm{~min}$. Irradiance was maintained at $250 \mu \mathrm{mol} \cdot \mathrm{m}^{-2} \cdot \mathrm{s}^{-1}$ supplied $11 \mathrm{~h} /$ day $(9.9$ $\mathrm{mol} \cdot \mathrm{m}^{-2} \cdot \mathrm{d}^{-1}$ ) by cool-white fluorescent lamps (Philips VHOF96T12/ CW/VHO, Bloomfield, Pa.) and incandescent bulbs (Sylvania 60W) with an input wattage of $77 \%$ and $23 \%$, respectively. Lamps were raised as required to maintain the photosynthetic photon flux (PPF) at the canopy top.

Plants were subirrigated as required with a $14.3 \mathrm{~mm} \mathrm{~N}, 2.8 \mathrm{~mm}$ $\mathrm{P}$, and $4.3 \mathrm{~mm} \mathrm{~K}$ solution of $20 \mathrm{~N}-8.6 \mathrm{P}-16.6 \mathrm{~K}$ fertilizer at 2- or 3day intervals until they were 4 weeks old. After that time, plants were subirrigated at 1- or 2-day intervals until they were 6 weeks old, when the experiment was terminated.

Leaf number was recorded at 3- to 4-day intervals. Shoot and root DW, plant width (measured in two directions), leaf area, stem height, internode number, length of the internode below the first true leaf, and stem diameter were recorded after the sixth week of temperature treatment. Shoots and roots were weighed after drying for 3 days at $80^{\circ} \mathrm{C}$ in a forced-air oven. Leaf area was measured by an area meter (Delta-T Devices). Plant volume was calculated using the formula $3.14 \times($ width $1 \times$ width 2$) / 2 \times$ height, and a seedling index was calculated using the following formula (Song et al., 1989):

Seedling index $=$ dry weight $\times$ stem diameter/internode length where internode length was calculated by dividing stem height by the number of internodes.

Leaf reflectance was measured 16,30 , and 45 days after temperature treatments started for Expt. 1 and at 45 days in Expt. 2 using a spectrophotometer (model 986; X-Rite, Inc., Grandville, Mich.)

After 45 days of treatment, six plants from each treatment were 
Table 1. Growth and development responses of Capsicum annuum 'Resistant Giant no. 4' to day temperature (DT) and night temperature (NT).

\begin{tabular}{|c|c|c|c|c|c|c|c|c|c|c|c|c|c|c|c|}
\hline $\begin{array}{l}\text { DT } \\
\left({ }^{\circ} \mathrm{C}\right)\end{array}$ & $\begin{array}{l}\mathrm{NT} \\
\left({ }^{\circ} \mathrm{C}\right)\end{array}$ & $\begin{array}{l}\mathrm{ADT}^{\mathrm{z}} \\
\left({ }^{\circ} \mathrm{C}\right)\end{array}$ & $\begin{array}{l}\mathrm{DIF}^{\mathrm{y}} \\
\left({ }^{\circ} \mathrm{C}\right)\end{array}$ & $\begin{array}{l}\text { Stem } \\
\text { length } \\
(\mathrm{cm})\end{array}$ & $\begin{array}{l}\text { Internode } \\
\text { length } \\
(\mathrm{cm})\end{array}$ & $\begin{array}{l}\text { Shoot } \\
\text { dry wt } \\
\text { (g) }\end{array}$ & $\begin{array}{l}\text { Root } \\
\text { dry wt } \\
\text { (g) }\end{array}$ & $\begin{array}{l}\text { Root: } \\
\text { shoot } \\
\text { ratio }\end{array}$ & $\begin{array}{c}\text { Seedling } \\
\text { index }\end{array}$ & $\begin{array}{c}\text { Plant } \\
\text { vol } \\
\left(\mathrm{cm}^{3}\right)\end{array}$ & $\begin{array}{c}\text { Plant } \\
\text { canopy } \\
\text { area } \\
\left(\mathrm{cm}^{2}\right)\end{array}$ & $\begin{array}{l}\text { Stem } \\
\text { diam } \\
(\mathrm{mm})\end{array}$ & $\begin{array}{l}\text { Leaf } \\
\text { area } \\
\left(\mathrm{cm}^{2}\right)\end{array}$ & $\begin{array}{c}\text { No. } \\
\text { of } \\
\text { leaves }\end{array}$ & $\begin{array}{l}\text { Node } \\
\text { of } \\
\text { first } \\
\text { flower }\end{array}$ \\
\hline 14 & 14 & 14.0 & 0.00 & 4.8 & 1.15 & 169 & 36 & 0.21 & 0.6 & 208 & 43 & 2.56 & 19 & 5.2 & 12.2 \\
\hline 14 & 18 & 16.2 & -4 & 5.7 & 2.05 & 225 & 49 & 0.22 & 1.1 & 324 & 65 & 2.90 & 33 & 7.4 & 12.5 \\
\hline 14 & 22 & 18.3 & -8 & 8.9 & 2.88 & 327 & 58 & 0.18 & 1.2 & 843 & 93 & 3.24 & 59 & 8.0 & 11.8 \\
\hline 14 & 26 & 20.5 & -12 & 9.7 & 2.13 & 395 & 86 & 0.22 & 1.8 & 1451 & 131 & 3.55 & 84 & 10.2 & 11.3 \\
\hline 18 & 14 & 15.8 & 4 & 7.7 & 3.15 & 269 & 40 & 0.15 & 1.1 & 544 & 62 & 3.28 & 43 & 7.8 & 12.2 \\
\hline 18 & 18 & 18.0 & 0 & 8.5 & 3.32 & 277 & 51 & 0.18 & 1.3 & 780 & 76 & 3.91 & 56 & 8.4 & 11.7 \\
\hline 18 & 22 & 20.2 & -4 & 10.4 & 3.97 & 324 & 55 & 0.17 & 1.3 & 989 & 104 & 3.93 & 59 & 8.6 & 11.7 \\
\hline 18 & 26 & 22.3 & -8 & 12.8 & 3.05 & 429 & 70 & 0.16 & 1.8 & 1916 & 181 & 4.20 & 102 & 10.6 & 11.0 \\
\hline 22 & 14 & 17.7 & 8 & 10.4 & 3.67 & 317 & 53 & 0.17 & 1.2 & 907 & 113 & 3.96 & 63 & 8.4 & 13.0 \\
\hline 22 & 18 & 19.8 & 4 & 13.0 & 3.68 & 440 & 64 & 0.15 & 1.6 & 1783 & 140 & 4.20 & 97 & 9.6 & 11.0 \\
\hline 22 & 22 & 22.0 & 0 & 14.5 & 4.37 & 435 & 65 & 0.15 & 1.3 & 2146 & 166 & 3.91 & 96 & 9.8 & 11.7 \\
\hline 22 & 26 & 24.2 & -4 & 11.4 & 3.43 & 372 & 67 & 0.18 & 1.7 & 1823 & 139 & 4.30 & 104 & 10.0 & 10.8 \\
\hline 26 & 14 & 19.5 & 12 & 11.4 & 3.30 & 342 & 51 & 0.15 & 1.2 & 1210 & 130 & 3.90 & 77 & 8.6 & 11.8 \\
\hline 26 & 18 & 21.7 & 8 & 14.2 & 4.10 & 415 & 56 & 0.13 & 1.2 & 2240 & 148 & 3.81 & 97 & 9.4 & 11.3 \\
\hline 26 & 22 & 23.8 & 4 & 14.8 & 4.52 & 465 & 63 & 0.14 & 1.3 & 2471 & 194 & 3.91 & 108 & 9.4 & 11.2 \\
\hline 26 & 26 & 26.0 & 0 & 14.8 & 3.90 & 458 & 66 & 0.14 & 1.6 & 2146 & 165 & 4.18 & 114 & 10.4 & 11.2 \\
\hline \multicolumn{16}{|c|}{ Significance } \\
\hline & & & & $* * *$ & $* * *$ & $* * *$ & NS & $* * *$ & $*$ & $* * *$ & $* * *$ & $* * *$ & $* *$ & $* * *$ & NS \\
\hline \multicolumn{2}{|c|}{ Linear } & & & $* * *$ & $* * *$ & $* * *$ & NS & $* * *$ & NS & $* * *$ & $* * *$ & $* * *$ & $* *$ & $* * *$ & NS \\
\hline \multicolumn{3}{|c|}{ Quadratic } & & $*$ & $* * *$ & NS & NS & NS & $*$ & NS & NS & $* * *$ & NS & $* *$ & NS \\
\hline \multicolumn{2}{|c|}{ NT } & & & $* * *$ & $* * *$ & $* * *$ & $* * *$ & NS & $* * *$ & $* * *$ & $* * *$ & $* * *$ & $* * *$ & $* * *$ & $* * *$ \\
\hline \multicolumn{2}{|c|}{ Linear } & & & $* * *$ & $* * *$ & $* * *$ & $* * *$ & NS & $* * *$ & $* * *$ & $* * *$ & $* * *$ & $* * *$ & $* * *$ & $* * *$ \\
\hline \multicolumn{2}{|c|}{ Quadratic } & & & $* *$ & $* * *$ & $*$ & NS & NS & NS & NS & NS & NS & NS & NS & NS \\
\hline \multicolumn{2}{|c|}{$\mathrm{DT} \times \mathrm{NT}$} & & & $* * *$ & NS & $* * *$ & $*$ & NS & NS & $* * *$ & $* * *$ & $* *$ & $* * *$ & $* *$ & NS \\
\hline \multicolumn{2}{|c|}{ DIF } & & & NS & $*$ & NS & $* * *$ & $* * *$ & $*$ & NS & NS & NS & NS & NS & NS \\
\hline \multicolumn{2}{|c|}{ Linear } & & & NS & $* *$ & NS & $* * *$ & $* *$ & $*$ & NS & NS & NS & NS & NS & NS \\
\hline \multicolumn{2}{|c|}{ Quadratic } & & & NS & NS & NS & $* *$ & $*$ & NS & NS & NS & NS & NS & NS & NS \\
\hline
\end{tabular}

${ }^{\mathrm{z}} \mathrm{ADT}=$ average daily temperature.

${ }^{\mathrm{y}} \mathrm{DIF}=\mathrm{DT}-\mathrm{NT}$.

Ns, ${ }^{*}, * * * * * *$ Nonsignificant or significant at $P<0.05,0.01$, or 0.001 , respectively.

transplanted to $15-\mathrm{cm}$ pots containing Metro Mix 510, and the pots were placed in a $21^{\circ} \mathrm{C}$ greenhouse. The node of flower set was recorded.

SAS's two-way analysis of variance (Proc GLM, SAS Institute, 1993) was completed for plant growth indices to determine significance of linear and quadratic DT and NT responses. Data were reanalyzed using one-way analysis of variance to determine linear and quadratic DIF responses. Predictive relationships between plant indices, ADT, and DIF were determined with SAS's Proc REG (SAS Institute, 1993).

\section{Results}

Stem length, leaf count, leaf area, plant volume, stem diameter, and shoot DW after 6 weeks of treatment increased as either DT or NT increased (Table 1); thus, each variable was a function of ADT (Figs. 1 and 2). The increase in stem length, leaf count, leaf area, plant volume, stem diameter, and shoot DW was $210 \%, 100 \%$, $500 \%, 930 \%, 60 \%$, and $170 \%$, respectively, as ADT increased from 14 to $26^{\circ} \mathrm{C}$. Stem length, leaf area, plant volume, and stem diameter were not statistically related to DIF when ADT was ignored (Table 1); however, each was highly correlated with DIF when regressed against DIF and ADT (Figs. 1 and 2). When ADT was similar, plants grown under negative DIF were shorter than those grown under positive DIF. The relationship of stem diameter and DIF was not distributed normally, since there was no relation- ship with DIF for most treatment means; however, a negative linear relationship existed between DIF and the $14{ }^{\circ} \mathrm{C}$ DT treatments (Fig. 3B). DIF had no effect on leaf count or shoot DW.

Internode length increased as ADT and DIF increased (Table 1, Figs. 2A and 3A). However, internode lengths were consistently shorter for a particular ADT on plants grown with $26^{\circ} \mathrm{C} \mathrm{NT}$ (Fig. $2 \mathrm{~A})$. When plotted against DIF, internode lengths of plants from the 14/14 and 14/18 DT/NT treatments were atypically short compared to those of other treatments (Fig. 3A).

Root DW increased as NT increased and as DIF decreased; there was no significant response to DT (Table 1). The root : shoot ratio decreased as DT and DIF increased (Table 1, Fig. 3C), and the proportion of DW partitioned to the roots decreased from about $22 \%$ to $13 \%$.

A large seedling index indicates a compact, high-DW seedling. Seedling index increased as either DT or NT increased (Table 1); thus, it was a function of ADT (Fig. 2D). The index increased from 0.6 to 1.6 as ADT increased from 14 to $26^{\circ} \mathrm{C}$. Since internode length was correlated negatively with DIF, seedling index decreased as DIF increased (Fig. 3D).

Leaf unfolding rate (LUR) was a function of ADT (Fig. 4). LUR doubled from about 0.1 to 0.2 leaves/day as ADT increased from 14 to $26^{\circ} \mathrm{C}$. The calculated base temperature and degree-days per leaf were $4.6^{\circ} \mathrm{C}$ and 87 , respectively, when a linear function was fit to data collected at an ADT below $21^{\circ} \mathrm{C}$. DIF had no effect on LUR.

Leaf reflectance was an indicator of leaf color. Reflectance was 
higher for plants grown under negative than positive DIF (Fig. 5). Differences in reflectance were very small below $500 \mathrm{~nm}$ and highest at $550 \mathrm{~nm}$. Reflectance at $550 \mathrm{~nm}$ increased from $10 \%$ to $15 \%$ when DIF decreased from 12 to-12, a 50\% increase (Figs. 5 and 6A). Most of the change in reflectance was a response to DT (Fig. 6B).

The node at which the first flower formed decreased about one node as NT increased from 14 to $26^{\circ} \mathrm{C}$ (Table 1). DT and DIF had no effect on the node at which the first flower initiated.

\section{Discussion}

The objectives of this research were to determine the response

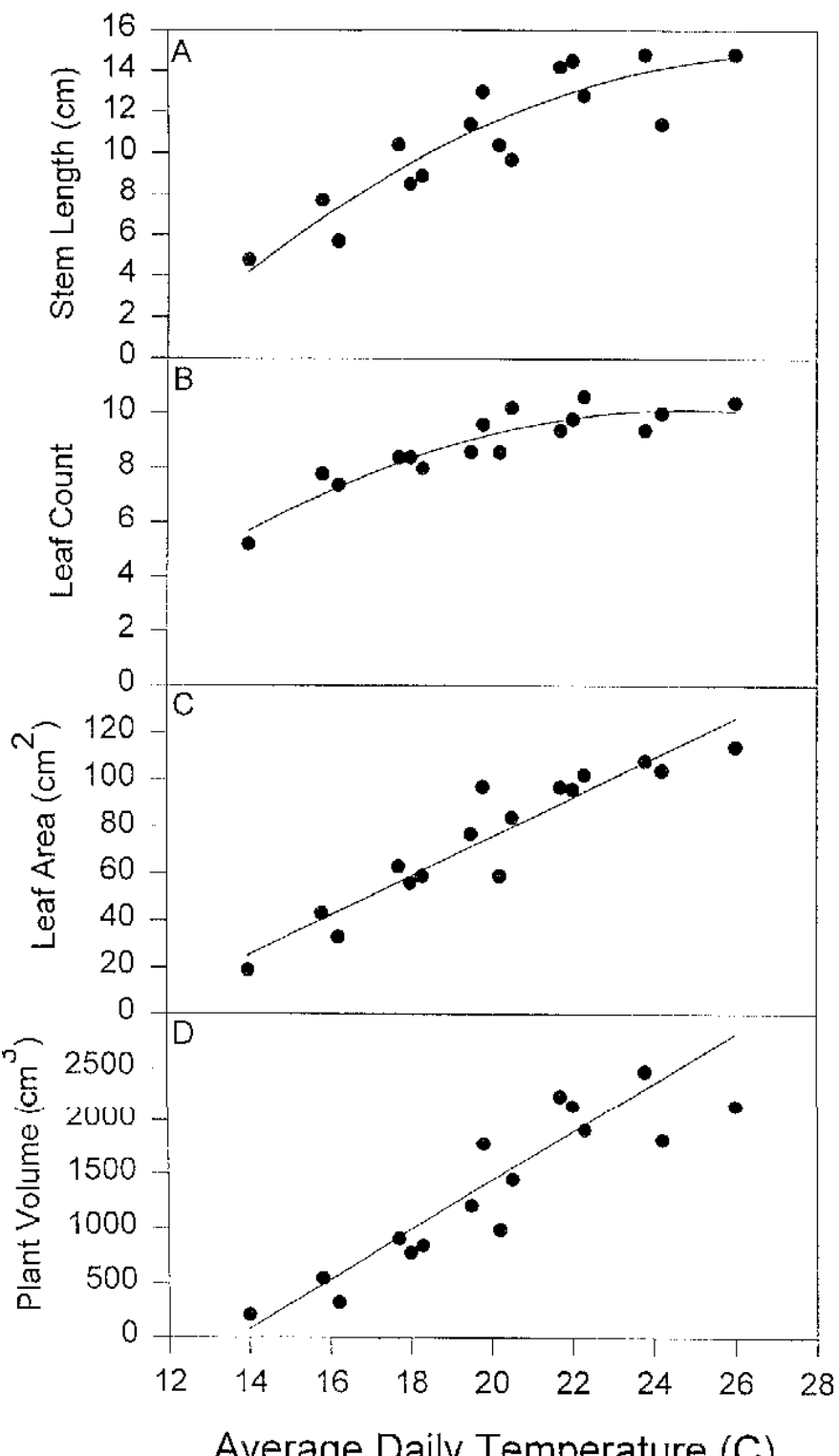

Fig. 1. Relationship between average daily temperature (ADT) and Capsicum anпиит 'Resistant Giant no.4' pepper. (A) Stem length. The solid line represents the regression function in which stem length $=-28.44+3.12 \times \mathrm{ADT}+0.16 \times \mathrm{DIF}$ $-0.056 \times \mathrm{ADT}^{2}\left(R^{2}=0.80\right)$. In the regression line, $\mathrm{DIF}$ was set to 0 . (B) Leaf count. The solid line represents the regression function in which leaf count $=-13.33+$ $1.89 \times \mathrm{ADT}-0.038 \times \mathrm{ADT}^{2}\left(R^{2}=0.64\right)$. (C) Leaf area. The solid line represents the regression function in which leaf area $=-92.44+8.41 \times \mathrm{ADT}+0.53 \times \mathrm{DIF}$ $\left(R^{2}=0.82\right)$. DIF was set to 0 for the regression line. (D) Plant volume. The solid line represents the regression function in which plant volume $=-3117+228.22$ $\times \mathrm{ADT}+28.51 \times \mathrm{DIF}\left(R^{2}=0.69\right)$. DIF was set to 0 for the regression line. of pepper seedlings to DT, NT, and DIF and to determine how this information might be used to manage pepper seedling production. The data showed that, for 'Resistant Giant no. 4', seedling stem length, internode length, stem diameter, leaf area, internode and leaf count, plant volume, shoot DW, seedling index, and LUR were primarily functions of ADT; i.e., DT and NT had similar effects on each growth or development parameter. DIF had a smaller but statistically significant effect on stem and internode length, leaf area, plant volume, stem diameter, and seedling index. DIF had no

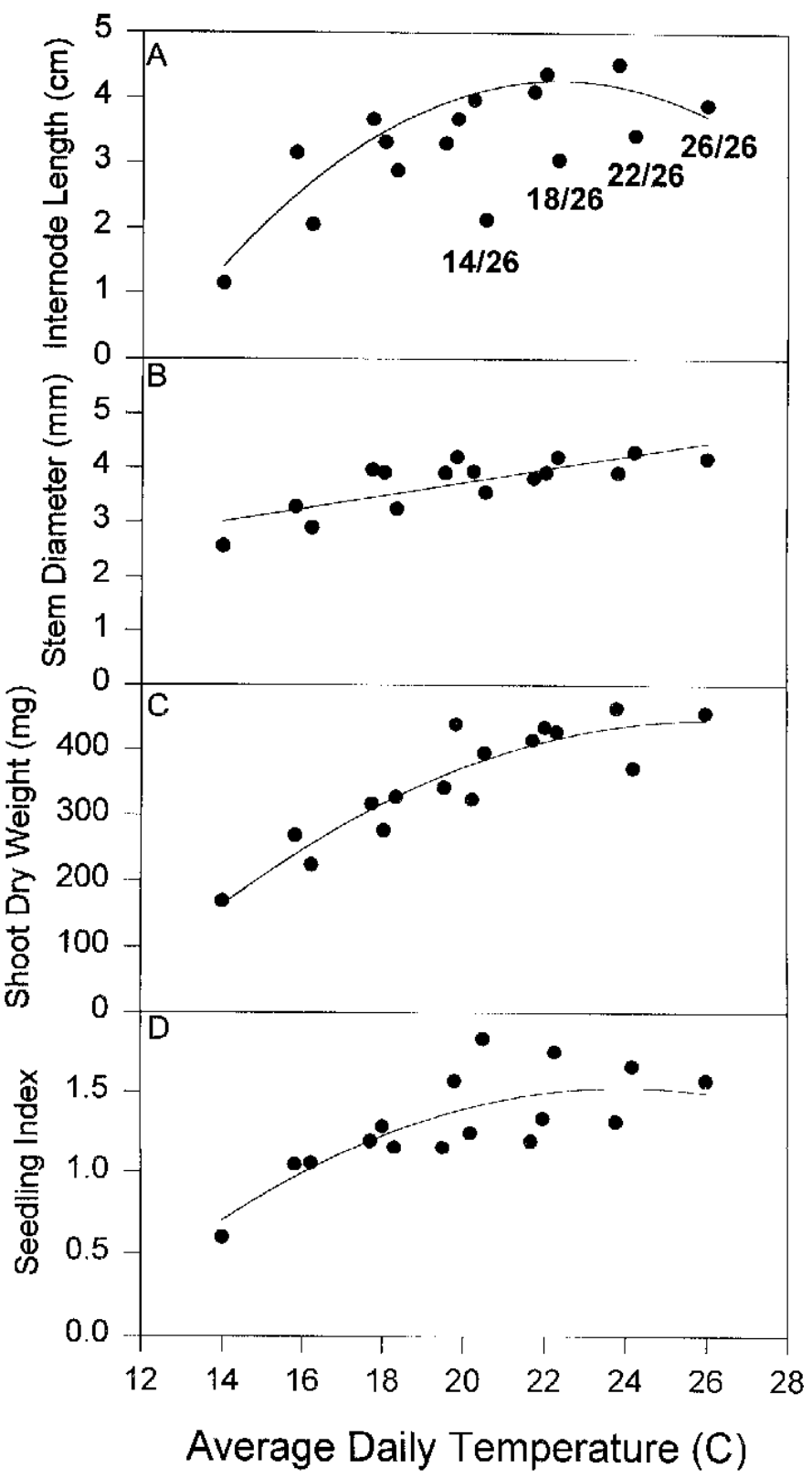

Fig. 2. Relationship between average daily temperature (ADT) and Capsicum annuиm 'Resistant Giant no. 4' pepper. (A) Internode length. The solid line represents the regression function in which internode length $=-16.16+1.83 \times$ ADT $+0.065 \times \mathrm{DIF}-0.041 \times \mathrm{ADT}^{2}-0.0086 \times \mathrm{DIF}^{2}\left(R^{2}=0.72\right)$. For regression line, $\mathrm{DIF}$ was set to 0. (B) Stem diameter. The solid line represents the regression function in which stem diameter $=1.30+0.12 \times \mathrm{ADT}+0.017 \times \mathrm{DIF}\left(R^{2}=0.53\right)$. For the regression line, DIF was set to 0 . (C) Shoot DW. The solid line represents the regression function in which shoot $\mathrm{DW}=-852.06+98.83 \times \mathrm{ADT}-1.88 \times \mathrm{ADT}^{2}$ $\left(R^{2}=0.69\right)$. (D) Seedling index. The solid line represents the regression function in which seedling index $=-3.24+0.40 \times \mathrm{ADT}-0.017 \times \mathrm{DIF}-0.0083 \times \mathrm{ADT}^{2}\left(R^{2}\right.$ $=0.42$ ). For the regression line, DIF was set to 0 . 
effect on internode and leaf count, shoot DW, and LUR. The root : shoot ratio and leaf reflectance were affected by DT and DIF, while the node at which the first flower initiated was related to NT.

The developmental responses of LUR, internode count, and leaf count are similar to those found for other species in which plant development rate is a function of the ADT rather than DT, NT, or DIF (Alm et al., 1988; Karlsson et al., 1988, 1989). One would expect internode and leaf count to have the same response to the environment as LUR because LUR is a number calculated from

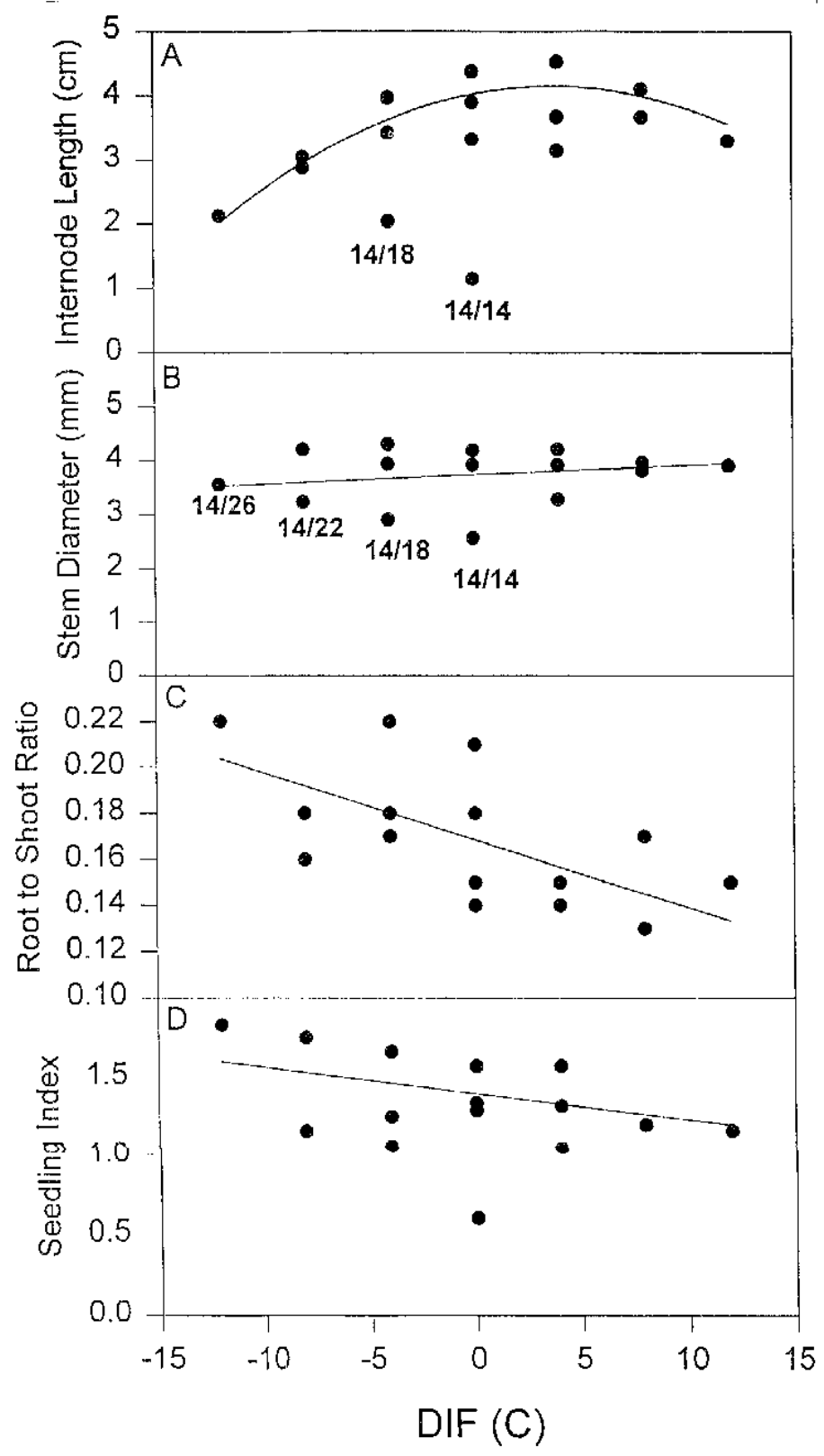

Fig. 3. Relationship between Capsicum annиum 'Resistant Giant no. 4' pepper and the difference between day and night temperature (DIF). (A) Internode length. The solid line represents the regression function in which internode length $=-$ $16.16+1.83 \times \mathrm{ADT}+0.065 \times \mathrm{DIF}-0.041 \times \mathrm{ADT}^{2}-0.0086 \times \mathrm{DIF}^{2}\left(R^{2}=0.72\right)$. For the regression line, ADT (average daily temperature) was set to 20. (B) Stem diameter. The solid line represents the regression function in which stem diameter $=1.30+0.12 \times \mathrm{ADT}+0.017 \times \mathrm{DIF}\left(R^{2}=0.53\right)$. For the regression line, $\mathrm{ADT}$ was set to 20. (C) Root : shoot ratio. The solid line represents the regression function in which ratio $=0.27-0.0049 \times$ ADT $-0.0029 \times \operatorname{DIF}\left(R^{2}=0.34\right)$. For the regression line, ADT was set to 20 . (D) Seedling index. The solid line represents the regression function in which seedling index $=-3.24+0.40 \times \mathrm{ADT}-0.017 \times$ $\mathrm{DIF}-0.0083 \times \mathrm{ADT}^{2}\left(R^{2}=0.42\right)$. For the regression line, ADT was set to 20 . leaf count over time. LUR is often described as a linear function of ADT within a species' specific limited temperature range (Alm et al., 1988; Karlsson et al., 1988; Ritchie, 1991). For pepper, LUR could be described by a linear model from 14 to about $20^{\circ} \mathrm{C}$ (Fig. 4). Using the linear model, the base temperature for pepper LUR is about $5^{\circ} \mathrm{C}$, and 87 degree-days are required to unfold one leaf.

One would expect pepper seedling stem length to be correlated with ADT, since a stem length is determined by number and length of internodes and internode count increased as ADT increased (Fig. 1B). Stem and internode length also were influenced by DIF (Fig. 3A). These results are consistent with previous research that showed internode and stem length were influenced by DIF and .ADT (Erwin et al., 1989; Karlsson et al., 1989; Went, 1952).

For chrysanthemum, Fuchsia $\times$ hybrida 'Dollar Princess', and Pelargonium Xhortorum L.H. Bailey 'Red Elite', Erwin et al. '(1991) reported that total chlorophyll concentration and the chlorophyll $a: b$ ratio were affected by DIF and ADT. Total chlorophyll per unit of leaf area and per unit of leaf DW increased with increasing positive DIF. Although chlorophyll was not quantified in this experiment, leaf reflectance increased at wavelengths above $500 \mathrm{~nm}$ as DT decreased (DIF decreased), indicating decreasing leaf chlorophyll as DIF decreased from positive to negative. Plants were visibly more chlorotic as DIF decreased. These results are the same as those reported for other crops under negative DIF temperature conditions (Berghage et al., 1991; Erwin et al., 1991; Heins and Erwin, 1990).

Studies by Agrawal et al. (1993) indicated that Cucumis sativus ('Poinsett' and 'Ashley') plants grown under negative DIF produced one-half to one-third less growth than those grown under

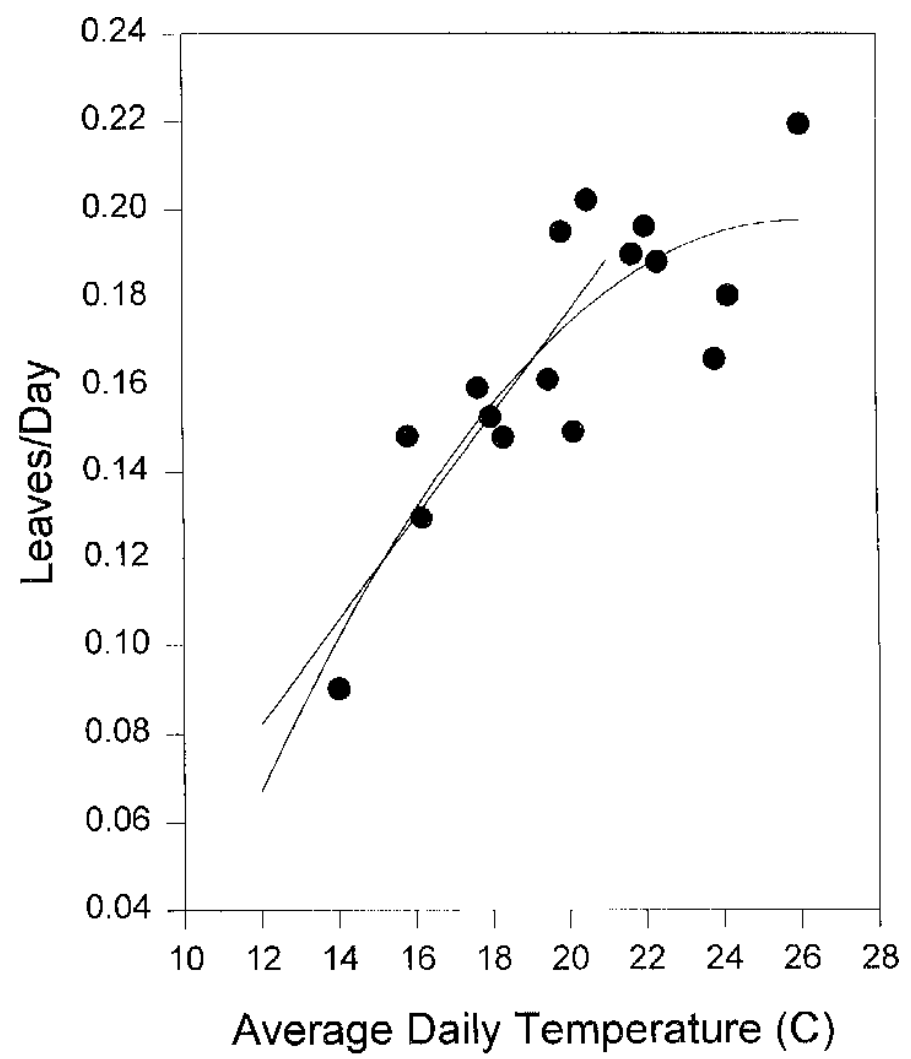

Fig. 4. Leaf unfolding rate (LUR) of Capsicum annuum 'Resistant Giant no. 4' in response to average daily temperature (ADT). The solid curved line represents the regression function in which LUR $=-0.25+0.035 \times \mathrm{ADT}-0.00067 \times \mathrm{ADT}^{2}\left(R^{2}\right.$ $=0.73$ ), while the linear line at $\mathrm{ADT}$ below $21{ }^{\circ} \mathrm{C}$ represents the regression function in which $\mathrm{LUR}=-0.054+0.012 \times \mathrm{ADT}\left(R^{2}=0.79\right)$. 
positive DIF, based on stem height, leaf area, and top DW. In our research, pepper plugs grown at negative DIF (18/22 DT/NT) were $20 \%$ shorter and had $26 \%$ and $39 \%$ less leaf area and shoot DW, respectively, compared to those grown at positive DIF (22/18 DT/ NT). Likewise, plant canopy area and root DW were $26 \%$ and $14 \%$ less for negative-DIF-grown plants. The reduction in DW is likely related to reduced photosynthesis associated with less leaf chlorophyll and lower leaf temperatures.

Rylski (1972) found that low temperature caused a delay in pepper anthesis and an increase in the number of leaves formed before the first flower when the plants were exposed to low temperature from the cotyledon stage to the three-leaf stage and that low night temperature caused more leaves to form before first flower. Our findings are similar.

The seedling index was developed to merge plant DW, internode length, and stem diameter data into a useful tool to identify plants with desirable horticultural characteristics. The ideal seedling transplant would, on a relative scale, have high DW, thick stems, and short internodes (Song et al., 1989). Such a seedling should be easier to transplant to the field and more tolerant of transplant stress than a seedling with low DW, thin stems, and long internodes. The seedling index used in this study combined these three plant properties into one number. Seedling index was a function of ADT and DIF; it increased as ADT increased from 14 to about $20^{\circ} \mathrm{C}$ and as DIF decreased. The direct effect of ADT on the index was through increased DW, and that of DIF through decreased internode length. Not included in the index, but important to early production, is the node of first flower that decreased as NT increased. A combination of all parameters suggests that the

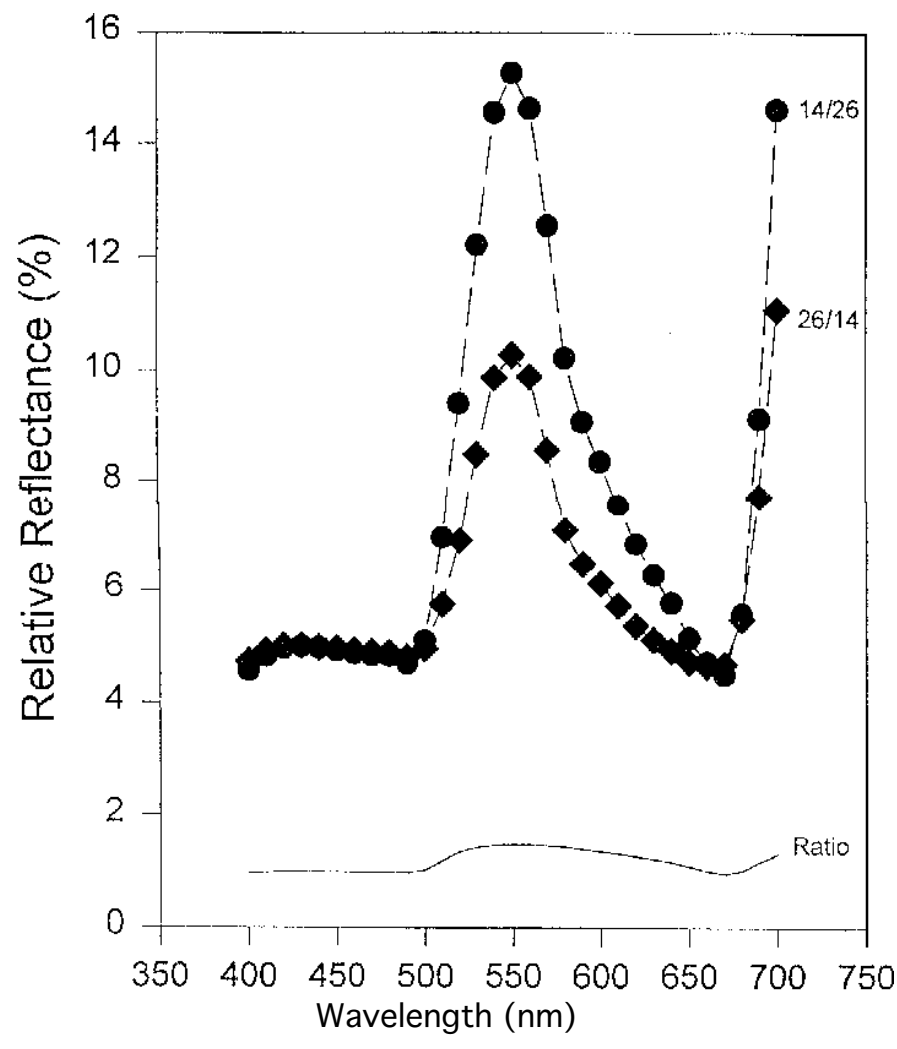

Fig. 5. Effect of positive and negative DIF (difference between day and night temperature) on relative leaf reflectance of Capsicum annuum 'Resistant Giant no. 4'. DT/NT were 14/26( $(\bullet)$ and 26/14 ( ). The solid line represents the ratio of leaf reflectance between $14 / 26$ and 26/14 DT/NT.
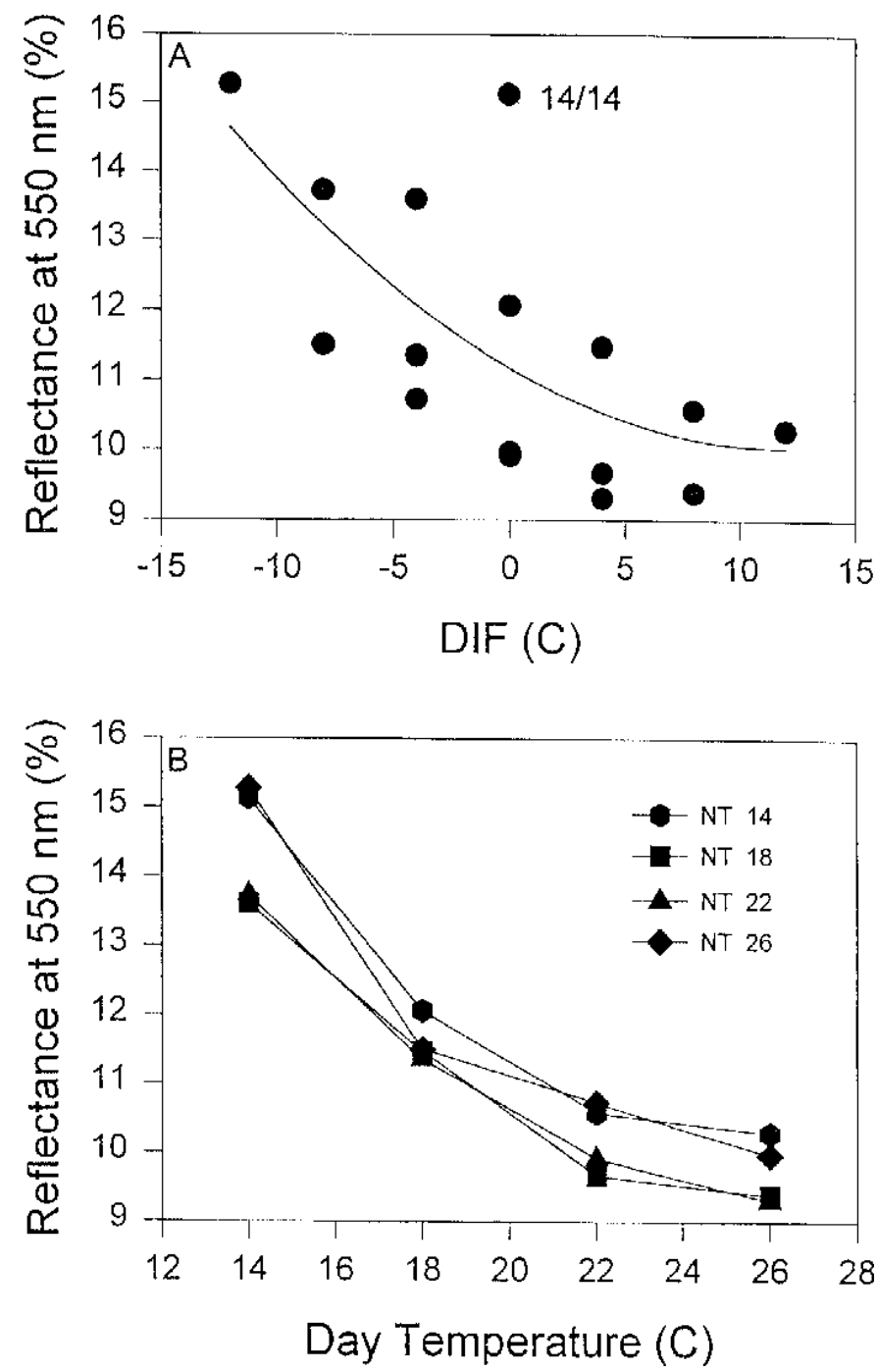

Fig. 6. Relationship between Capsicum annиum 'Resistant Giant no. 4' relative leaf reflectance at $550 \mathrm{~nm}$ and (A) difference between day and night temperature (DIF) and (B) day temperature (DT). The solid line represents the regression function in which leaf reflectance $=11.18-0.19 \times \mathrm{DIF}+0.0081 \times \mathrm{DIF}^{2}\left(\mathrm{R}^{2}=\right.$ 0.45 ). Average daily temperature (ADT) was set to 0 for the regression line.

optimum conditions for production of pepper seedling transplants is to grow the plants with an ADT of at least $20^{\circ} \mathrm{C}$ under negative DIF. We suggest a DT of 18 to $20^{\circ} \mathrm{C}$ and an NT of 22 to $26^{\circ} \mathrm{C}$.

\section{Literature Cited}

Agrawal, M., T.K. Donald, S.B. Agrawal, G.F. Kramer, E.H. Lee, R.M. Mirechi, and R.A. Rowland. 1993. Influence of inverse day/night temperature on ozone sensitivity and selected morphological and physiological responses of cucumber. J. Amer. Soc. Hort. Sci. 118:649-654.

Alm, D.M., D.R. Pike, J.D. Hesketh, and E.W. Stoller. 1988. Leaf area development in some crops and weed species. Biostronics 17:29-39.

Berghage, R.D., J.E. Erwin, and R.D. Heins. 1991. Photoperiod influenced leaf chlorophyll content in chrysanthemum grown with a negative DIF temperature regime. HortScience 26:708.

Deli, J. and H. Tiessen. 1969. Interaction of temperature and light intensity on flowering of Capsicum frutescens var. grossum cv. California Wonder. J. Amer. Soc. Hort. Sci. 94:349-351.

Erwin, J. E. 1991. Thermomorphogenesis. PhD diss., Michigan State Univ., East Lansing.

Erwin, J.E., R.D. Berghage, and R.D. Heins. 1991. Circadian temperature effects on plant chlorophyll content. HortScience 26:721.

Erwin, J.E., R.D. Heins, and J.E. Faust. 1993. Thermomorphogenic and 
photoperiodic responses of Nephrolepis exaltata 'Dallas Jewel'. HortScience 28:182-184.

Erwin, J.E., R.D. Heins, and M.G. Karlsson. 1989. Thermomorphogenesis in Lilium longiflorum Thunb. 'Nellie White'. Amer. J. Bot. 76(1):47-52.

Erwin, J.E., R.D. Heins, W. Carlson, and S. Newport. 1992. Diurnal temperature fluctuations and mechanical manipulation affect plant stem elongation. PGRSA Quarterly 20:1-17.

Heins, R. and J. Erwin. 1990. Understanding and applying DIF. Greenhouse Grower 10:73-78.

Karlsson, M.G., R.D. Heins, and J.E. Erwin. 1988. Quantifying temperature-controlled leaf unfolding rates in 'Nellie White' Easter lily. J. Amer. Soc. Hort. Sci. 113:70-74.

Karlsson, M.G., R.D. Heins, J.E. Erwin, and R.D. Berghage. 1989. Development rate during four phases of chrysanthemum growth as determined by preceding and prevailing temperatures. J. Amer. Soc. Hort. Sci. 114:234-240.

Moe, R. and R.D. Heins. 1990. Control of plant morphogenesis and flowering by light quality and temperature. Acta Hort. 272:81-89.

Pinthus, M.J. and J. Meiri. 1979. Effects of reversal of day and night temperatures on tillering and on the elongation of stems and leaf blades of wheat. J. Expt. Bot. 30:319-326.

Ritchie, J.T. 1991. Temperature and crop development, p. 5-27. In: John Hanks and J.T. Ritchie (eds.). Modeling plant and soil systems. Amer. Soc. Agron.

Rylski, I. 1972. Effect of the early environment on flowering in pepper (Capsicum annuum L.). J. Amer. Soc. Hort. Sci. 97:648-651.

SAS Institute. 1993. SAS companion for the Microsoft Windows environment. SAS Institute, Cary, N.C.

Song, Yuanlin, Q. He, and H. Tan. 1989. Modern raising seedling of vegetables. Agr. Sci. Technol. Publishing House, China.

Tageras, H. 1979. Modifying effects of ancymidol and gibberellins on temperature induced elongation in Fuchsia xhybrida. Acta Hort.91:411417.

Went, F.W. 1944. Plant growth under controlled conditions. II. Thermoperiodicity in growth and fruiting of the tomato. Amer. J. Bot. 31:135150.

Went, F.W. 1952. The effect of temperature on plant growth. Annu. Rev. Plant Physiol. 4:347-362.

Went, F.W. 1957. The experimental control of plant growth. Chronica Botanica 17:1-126. Ronald Press, New York. 